\title{
Induction od resistance against Penicillin expansum in harvested apple fruits using walnut green water extract
}

\author{
Esmaeil Zangoei ${ }^{1}$, Eidi Bazgir ${ }^{2 *}$, Jalal Gholamnezhad ${ }^{3}$ and Mostafa Darvishnia ${ }^{2}$ \\ ${ }^{1}$ Student of Plant Pathology, Department of Plant Pathology, College of Agriculture, \\ University of Lorestan, Lorestan, Iran. \\ ${ }^{2}$ Department of Plant Protection, Agriculture Faculty, Lorestan University, Lorestan Province, Iran. \\ ${ }^{3}$ Department of Horticultural Sciences, Faculty of Agriculture \& Natural Resources, Ardakan University, P.O. Box 184, \\ Ardakan 8951895491, Iran. \\ *Corresponding author. Email: bazgir.ei@lu.ac.ir
}

Copyright (C) 2020 Zangoei et al. This article remains permanently open access under the terms of the Creative Commons Attribution License 4.0, which permits unrestricted use, distribution, and reproduction in any medium, provided the original work is properly cited.

Received 25th July, 2020; Accepted 10th September, 2020

\begin{abstract}
In this study, apple fruits were first treated with different concentrations $(1.5,3,4.5$ and $6 \times 1000)$ of walnut green skin water extract and Penicillium expensum pathogen. The activity of defense enzymes including of phenylalanine ammonia-lyase, polyphenol oxidase, superoxide dismutase and $\beta(1,3)$ glucanase were measured in the treated apple fruits in the sampling days, 3, 6, 9, 12, and 15 days after pathogen induction of fruit. Then, genes expression levels encoding these enzymes were assessed by Real-time PCR. The results showed that the activity of the studied enzymes increased from the third day of sampling to the 9th day and then decreased until the 15th day. Pathogen and walnut green skin both increased the enzyme activity. As the concentration of the walnut green skin extracts increased, the activity of the enzymes increased. The highest activity of PAL, PPO, SOD and Glu enzymes was observed at day 9 at concentrations of $6 \times 1000$ with values 11.28 (U per mg protein), 5.37 ( $\Delta$ OD per min per $\mathrm{mg}$ of total protein), 26.87 ( $\mathrm{U}$ per mg mg protein) and 23.89 ( $\triangle \mathrm{OD}$ per min per $\mathrm{mg}$ of total protein), respectively. The results of measurement of gene expression were also in accordance with the activity of enzymes. Exactly on the 9th day, the highest gene expression was observed for the genes expressing each enzyme and in the treatment of both pathogens and extracts. The gene expression levels of PAL, PPO, SOD and Glu enzymes at 9th day and in apple treated with pathogen and green walnut skin extracts were 121, 148, 150 and 148 times higher than those genes in the healthy apples as control, respectively.
\end{abstract}

Keywords: Antioxidant enzymes, apple blue mold, Penicillium expansum, walnut green skin.

\section{INTRODUCTION}

The apple fruit is a main and common crop in the world and Iran (Gholamnejad et al., 2009). Consumers are increasingly searching fruits of consistent high quality (Niem et al., 2007). Long term storage of apple fruits without significant loss of quality is greatly important (Weber, 2011). Post-harvest losses of fruits and vegetables are high, ranging from 10 and $40 \%$ depending on the species and technologies used in the storage (Sever et al., 2012). Higher risk of fungal agents could lower the shelf-life of apple fruits during transportation and storage. Some qualitative and quantitative fruit losses are mainly due to pathogenic fungi which usually infect the host through wounds made during harvest, handling and processing (Wilson and Wisniewski, 1994). Apple rot is an economically significant disease on apple and can be caused by several pathogenic filamentous fungi with worldwide distribution like Penicillium expansum Link. and Botrytis cinerea Pers. that are common and causing significant economic losses in the USA and all over the world (Sutton et al., 2014). Penicillium sp. pathogen is also a major producer of patulin, a mycotoxin which can reach high concentrations in infected apples and pears (Battilani et al., 2008) and has cytotoxic, genotoxic and immunosuppressive activities (Araji et al., 2014). Despite the widespread use of modern storage facilities and techniques, synthetic chemical fungicides such as carbendazime, 
fludioxonil and benlyte are frequently used before or after harvest to control apple molds (Sever et al., 2012; Xiao et al., 2011). However, chemical compounds are increasingly limited because of environmental and toxicological risks as well as the onset of fungicide-resistant strains of fungal pathogens (Aked et al., 2001; Unnikrishnan and Nath, 2002). In the absence of safely effective post-harvest fungicides, alternative or integrative measures are becoming increasingly important in managing post-harvest diseases in the storage. To solve the problem of chemical fungicide resistance and to fight against certain physiological disorders of apples linked to alternative methods such as biological control was used (Wilson et al., 1999; Perring, 1986).

Biological control by antagonistic microorganisms is a promising tool for preventing post-harvest fungal rots and minimizing the use of fungicides (Gholamnejad, 2009; Ippolito et al., 2004). However, biocontrol agents are sometimes not sufficient to control fungal infections when applied alone under practical conditions and their use should be integrated with other methods (Janisiewicz et al., 2003).

There is an increasing interest in discovering the fungicide compounds from the plants or/plant products (Bernardo et al., 2015). A novel approach to control postharvest pathogens and thereby extends the shelf life is by the use of natural plant extracts, known to have minimal environmental impact and danger to consumers in contrast to synthetic pesticides (Tripathi and Dubey, 2004).

These fungicides are generally considered to be nonpersistent under field conditions as they are readily transformed by light, oxygen and microorganisms into less toxic products. Therefore, no residues are expected on the products or in the environment (Javed et al. 2006).

Many plant extracts have potential as natural antimicrobial agents that can be applied to agricultural produces, foods and pharmaceutics (Maoz and Neeman, 1998) because they contain a phytochemical that exhibits antimicrobial and cytotoxic effects on microorganisms (Feldberg et al., 1988). Examples include allyl isothiocyanate from mustard which is able to inhibit the growth of $P$. expansum (Mari et al., 2002), phenolic compounds in thyme oil which exhibited antimicrobial effects on food-borne bacteria (Cosentino et al., 1999).

Plant extracts can act as an elicitor to stimulate the host plant's defense system. Transcript analysis has been effectively employed to probe defense responses induced by elicitors including yeast activated tomato genes encoding SAR-dependent PRs (chitinase and glucanase), cytochrome P450s and cell wall loosening enzymes (Morales et al., 2010). In Arabidopsis transcriptional analysis has identified elicitor induced acclamatory responses to stress, such as recovery of the cell redox balance, intracellular stress signaling, and improved pathogen recognition (Blanco et al., 2009). While activation of defense responses by plant elicitors can protect against pathogens, an inhibition of the biosynthesis of photosynthetic pigments and photosynthetic activity reducing plant productivity can also occur (Mari et al., 2012).

There are few reports (Gholamnezhad, 2019) on the effect of plant extracts as a post-harvest treatment for controlling blue mold of apples or even other diseases of post-harvest fruits. Therefore, this study aimed to evaluate the efficacy of walnut green skin extract (WGSE) as a postharvest treatment for controlling $P$. expansum attacking apple fruits, its effect of the activity of some antioxidant enzymes and expression of related genes under cold storage conditions.

\section{MATERIALS AND METHODS}

\section{Pathogen \\ $P$. expansum Link strain $\mathrm{P} 1$ was obtained from University of Tehran, College of Abouraihan, Department of Entomology and Plant Pathology and was maintained on half strength potato dextrose agar (PDA: $15 \mathrm{~g}$ potato dextrose broth (PDB), $15 \mathrm{~g}$ agar in $1000 \mathrm{ml}$ of water) at $4^{\circ} \mathrm{C}$. A conidial suspension was prepared according to the method used by Errampalli (2004). The conidia were enumerated with a Petroff-Hauser counting chamber and conidial suspensions were adjusted to the appropriate concentration with sterile distilled water.}

\section{Fruit}

Apple (Malus domestica Borkh.) fruits were harvested at commercial maturity in the Semirum, Isfehan, Iran. Fruit were selected for their uniform size and absence of blemishes or visible rot. Harvested fruit were stored at $4{ }^{\circ} \mathrm{C}$ prior to treatment. Fruits were surface disinfected with $5 \%$ sodium hypochlorite and $0.01 \%$ Tween 20 for 4 minutes, rinsed with tap water for 5 minutes, and dried before wounding.

\section{Plant extracts}

The walnut was obtained from the experimental gardens of the Iran and extracted in the post-harvest laboratory of the Institute. The walnut green skin was used for the extraction (WGSE). The extraction procedures of the plant materials were based on the method described by Yuliani and Rusli (2003). In short, $100 \mathrm{~g}$ material was dried in the sun for 4 to 5 days, then ground using $2 \mathrm{~mm}$ grinder. To the $100 \mathrm{~g}$ powder, 1 litre of distilled water was added followed by 3 hours mixing at $500 \mathrm{rpm}$ using an electric mixer made by Karl Kolb (Dreieich, Germany). Subsequently, the mixture was left overnight in the dark at $28 \pm 1^{\circ} \mathrm{C}$ to allow further extraction of the active ingredients. After this, the mixture was filtered using Whatman no. 91 filter paper and the residues were soaked and shaken again in 1 litre of distilled water for 2 hours. 
The solution was filtered again and the first and second filtrate were mixed and concentrated using a Rota vapor at $45^{\circ} \mathrm{C}$ for approximately 3 hours until all water was removed. The extracts were transferred into dark glass bottles and stored at $4{ }^{\circ} \mathrm{C}$. On the following week, about 10 $\mathrm{ml}$ of each extract were poured into $20 \mathrm{ml}$ of glass bottles and they were stored at $20^{\circ} \mathrm{C}$ in the laboratory until further use.

\section{In vivo test}

\section{Assessment of enzymes activity}

Apple fruits were inoculated according to the method described by Vero et al. (2002). Briefly, after surface disinfection with sodium hypochlorite $(0.1 \% \mathrm{v} / \mathrm{v})$ and rinsing with running tap water, three wounds $(3 \mathrm{~mm}$ deep $\times 1.5 \mathrm{~mm}$ wide) were made with a sterile needle on the equator of each fruit. The wounds were inoculated with 20 $\mu \mathrm{l}$ of a $P$. expansum suspension $\left(10^{6} \mathrm{CFU} / \mathrm{ml}\right)$. The control apples were inoculated with $20 \mu \mathrm{l}$ of sterile saline $(0.9 \%$ $\mathrm{NaCl}$ ). For each walnut green skin extract (WGSE) concentrations, three apple fruits were used. Inoculated apples were then placed in plastic boxes that were kept at room temperature. High humidity was maintained by adding some water to the bottom of the trays. After 24 hours, the apples were inoculated with different concentrations of WGSE as $1,2,4$ and $6 \times 1000$ (extract/water solution). The fruits were then incubated at $4^{\circ} \mathrm{C}$ and same conditions Vero et al. (2002).

After the test is over, the inoculated fruits were examined and two parameters including the activity of defense enzymes as well as the gene expression of these enzymes were measured. However, at the end of the experiment, the disease severity was evaluated by measuring the diameter of the spots on the apple and comparing them with the control, the data of which were not shown in this study.

\section{Enzyme activity}

The activities of four defense enzymes including phenylalanina ammonia-lyase (PAL), polyphenol oxidase (PPO), superoxide dismutase (SOD) and $\beta(1,3)$ glucanase $(\beta-1,3-g l u)$ were measured. The treated apples fruits similar to above mentioned methods were used for PAL, PPO, SOD and $\beta-1,3$-glu extraction at $3,6,9,12$, and 15 days after pathogen inoculation.

Sodium phosphate buffer $(0.1 \mathrm{mM}, \mathrm{pH}=6)$ was used to extract SOD and PPO and sodium acetate buffer $(0.05 \mathrm{mM}, \mathrm{pH}=5)$ was used to extract $\beta-1,3-\mathrm{glu}$. The fruit samples was homogenized in an ice cooled solution contain $50 \mathrm{n} \mathrm{mM}$ Tris- $\mathrm{HCl}$ buffer $(\mathrm{pH} 8.8)$ and $15 \mathrm{mM} \beta$ mercaptoethanol for PAL enzyme assay. This mixture was centrifuged at $10000 \mathrm{~g}$ for 12 minutes at room temperature, and then the supernatant was gathered for enzyme assays. The concentration of protein was measured according to Bradford method (Bradford, 1976) using BSA (bovine serum albumin) as standard protein.

Each treatment consisted of three replicates, and each replication contained 4 apples fruits. Apple fruits tissues from each treatment were sampled 1, 3, 5, 7, 9, 11 and 13 and 15 days after fungal pathogen incubation and squelch in a prechilled mortar and pestle. For isolate SOD, PPO and $\beta-1,3-g l u, 0.5 \mathrm{~g}$ of the sampled fruits was ground in liquid nitrogen with a suitable amount of the buffer and the mixture was centrifuged at $4^{\circ} \mathrm{C}$ for 25 minutes at $12000 \mathrm{~g}$. The supernatant liquid was pipetted to a $2 \mathrm{~mL}$ vial and kept at $4^{\circ} \mathrm{C}$ refrigerator (Gholamnezhad et al., 2016a).

\section{Phenylalanina ammonia-lyase (PAL) enzyme assay}

PAL activity was determined based on the rate of cinnamic acid production as described by Wang et al. (2006). Briefly, $1 \mathrm{ml}$ of the extraction buffer, $0.5 \mathrm{ml}$ of $10 \mathrm{mM} \mathrm{l-}$ phenylalanine, $0.4 \mathrm{ml}$ of double distilled water, and $0.1 \mathrm{ml}$ of enzyme extract were incubated at $37^{\circ} \mathrm{C}$ for 1 hour. The reaction was terminated by adding $0.5 \mathrm{ml}$ of $6 \mathrm{M} \mathrm{HCl}$, and the product was extracted with $15 \mathrm{ml}$ ethyl acetate, followed by evaporation to remove the extracting solvent. The solid residue was suspended in $3 \mathrm{ml}$ of $0.05 \mathrm{ml} \mathrm{NaOH}$ and the cinnamic acid concentration was quantified with the absorbance measured at $290 \mathrm{~nm}$. One unit of PAL activity equals to $1 \mathrm{mM}$ of cinnamic acid produced per min and expressed as $U$ per mg protein.

\section{Polyphenol oxidase (PPO) enzyme assay}

The activity of PPO was measured according to the method of Shi et al. (2001) method. The mixture of reaction $(2 \mathrm{~mL})$ containing $40 \mu \mathrm{g}$ of protein extract and $10 \mathrm{mM}$ phosphate buffer with $\mathrm{pH}=7.0$ was aerated for 2.5 minutes in a $2 \mathrm{ml}$ tube, and then catechol $(100 \mathrm{mM})$ was added as the substrate. The activity of PPO was presented as a change in absorbance of the reaction mixture at $420(\Delta O D /$ $\mathrm{min} / \mathrm{mg}$ of total protein).

\section{Superoxide Dismutase (SOD) enzyme assay}

SOD activity was measured according to winterbourne et al. (1975) with some modification. For each sample assayed, 6 tubes were setup containing 10, 20, 40, 60, 80 and $500 \mu \mathrm{l}$ of the enzyme extract. The reaction mixture contained $2 \mathrm{M}$ riboflavin, $10 \mathrm{mM}$ methionine, $50 \mathrm{M}$ nitroblue tetrazolium (NBT), $20 \mathrm{M} \mathrm{KCN}, 6.6 \mathrm{M} \mathrm{Na2EDTA}$, 10 to $500 \mathrm{~mm}$ of the enzyme extract, and $65 \mathrm{mM} \mathrm{NaKPi}$ buffer, pH 7.8, to give a total volume of $3.0 \mathrm{ml}$. SOD activity was assayed by measuring the capacity of the enzyme extract to inhibit the photochemical reduction of NBT. 
Glass test tubes were placed in $25^{\circ} \mathrm{C}$ and the reaction started by illumination under fluorescent light attached to the lid of a box with aluminium foil coated walls to provide uniform lighting. Blanks were obtained with nonilluminated duplicates. After 30 minutes illumination, absorbance was measured at $560 \mathrm{~nm}$. One unit of SOD was defined as the amount of enzyme causing half the maximum inhibition of NBT to blue formazan, and SOD activity of the extracts was expressed as SOD units (mg protein) $)^{-1}$.

\section{$\beta(1,3)$ glucanase (Glu) enzyme assay}

The activity of $\beta(1,3)$ glu was determined with laminarin dinitrosalicylate method described by Abeles and Forrence (1970) with a small amount of modification. The reaction mixture consisted of $35 \mu \mathrm{l} 4 \%$ laminarin (Merk, Germany) that was dissolved in $0.05 \mathrm{mM}$ sodium acetate buffer with $\mathrm{pH}=5$ and $30 \mu \mathrm{l}$ extract of plant was incubated at $40^{\circ} \mathrm{C}$. After 30 minutes, the reaction mixture was terminated by adding $187 \mu \mathrm{l}$ of dinitro-salicylic acid reagent (DNS, prepared by adding $300 \mathrm{~mL}$ of $4.5 \% \mathrm{NaOH}$ to $880 \mathrm{~mL}$ containing $8.8 \mathrm{~g}$ dinitrosalicylic acid (Merck, Germany) and $22 \mathrm{~g}$ potassium sodium tartrate) and it was heated for 5 minutes and the reaction mixture was diluted with $2 \mathrm{~mL}$ of distilled water and it was vortexed. The absorbance of resultant color at $500 \mathrm{~nm}$ was recoded. A standard curve relating absorbance at $500 \mathrm{~nm}$ to glucose concentration was used to measurement the activity of enzyme which was expressed as milligram glucose equivalent released per $(\mathrm{mg})$ total protein per minute (Anguelova-Merhar et al., 2001).

\section{Gene expression}

\section{Sampling procedures}

For the investigation of gene expression, apples were treated just like the experiment above and the treated apples were sampled. Apple samples were frozen immediately in liquid nitrogen after sampling and ground to a fine powder using a mortar and pestle. Four plants for each sample were harvested, placed in a labeled plastic bag and stored at $-80^{\circ} \mathrm{C}$.

\section{Total RNA extraction and cDNA synthesis}

Total RNA was extracted from $100 \mathrm{mg}$ of leaf tissue using a RNX- Plus Kit (Sina clon, Iran) according to the manufacturer's instructions. Extracted RNA was treated with DNase using a Qiagen RNase-Free DNase Set (Qiagen, Valencia, CA). Total RNA was visualized on a $1 \%$ agarose gel and then quantified and assessed for purity using a UV-visible spectrophotometer (CECIL 9500
Model, UK) (the results not shown). Sample purity was assessed using the ratio of absorbance at the $260 \mathrm{~nm}$ and $280 \mathrm{~nm}$ (A260/A280) wavelengths. Samples having A260/A280 more than 1.8 and less than 2 were considered acceptable for use quantitative Real-Time polymerase chain reactions (qPCR). Total RNA was quantified based on the standard conversion factor of 1 absorbance unit at $260 \mathrm{~nm}=40 \mathrm{mg} \mathrm{RNA} \mathrm{mL-1}$ (Tsai et al., 2004). For cDNA synthesis, $1 \mu \mathrm{g}$ of total RNA was used to synthesize cDNA with the Revert Aid Reverse Transcriptase Kit (Thermo Scientific, USA) according to the manufacturer's instructtions. cDNA synthesis products were stored at $-20^{\circ} \mathrm{C}$.

\section{Real time quantitative PCR}

RT-qPCR was performed in an optical 72-well plate using a Corbett RG-6000 Sequence Detection System. Each reaction contained $10 \mu \mathrm{l}$ of YTA SYBR Green qPCR Master Mix (Yekta Tajhiz Azma, Iran), $0.4 \mu \mathrm{M}$ of both forward and reverse gene specific primers, listed in Table 1 , and $50 \mathrm{ng}$ cDNA. The following thermal profile was used for all PCRs: $95^{\circ} \mathrm{C}$ for 10 minutes; 40 cycles of $95^{\circ} \mathrm{C}$ for 15 seconds and $60^{\circ} \mathrm{C}$ for 1 minutes. Data were evaluated using Rotor-Gene 6000 Software and Microsoft Excel. Exponential amplification was plotted on a logarithmic scale and the Rn was set to 0.24 for each RT-qPCR plate to obtain the cycle threshold $(\mathrm{Ct})$ values. Ct values for all genes were normalized to TEF-1 $\alpha$ of apple fruits to calculate variation between PCR runs or different CDNA samples. In addition, control samples were always run on the same plate as their respective treated samples. Primer efficiencies were determined using the LinRegPCR program (Ramakers et al., 2003).

\section{Statistical analysis}

All assays were carried out in a completely randomized design. Each treatment consisted of three replicates, and each replicate contained 3 plants for all enzyme activities. Statistical significance was assessed at the level $p<0.01$. When the analysis was statistically significant, Duncan's Multiple Range Test (SSR Test) was used to test mean separations among mean values of each treatment.

\section{RESULTS}

\section{PAL activity}

The PAL activity increased through all the sampling days in 1.5 to $6 \times 1000$ concentrations, reaching the maximum at 9 days after inoculation with pathogen and WGSE. The activity in $6 \times 1000$ concentration was higher than that in other treatments in either the presence of $P$. expansum inoculation and showed a significant difference in the all of 
Table 1. Sequences of selected gene primers used for real-time RT-PCR testing of polymerase chain reaction.

\begin{tabular}{llc}
\hline Name & Sequences & $\begin{array}{c}\text { Base } \\
\text { pare }\end{array}$ \\
\hline 3-1,3-glucanase & 5' GGGGAGATGTGAGGGGTTAT 3'-F \\
& 5' TGCAGTGAACAAAGCGTAGG 3' -R & 152 \\
Phenylalanine ammonia lyase & 5' ACAACAATGGACTGCCATCA 3'-F \\
& 5' CACTTTCGACATGGTTGGTG -R \\
Polyphenol oxidase & 5' CTTCTTGGTCTTGGAGGTCT 3'-F \\
& 5' ATCGGAGCTTGTCGTAGAG -R & \\
Superoxide Dismutase & 5' TGGATGGGTGTGGCTTGCT 3'-F & 160 \\
\hline
\end{tabular}

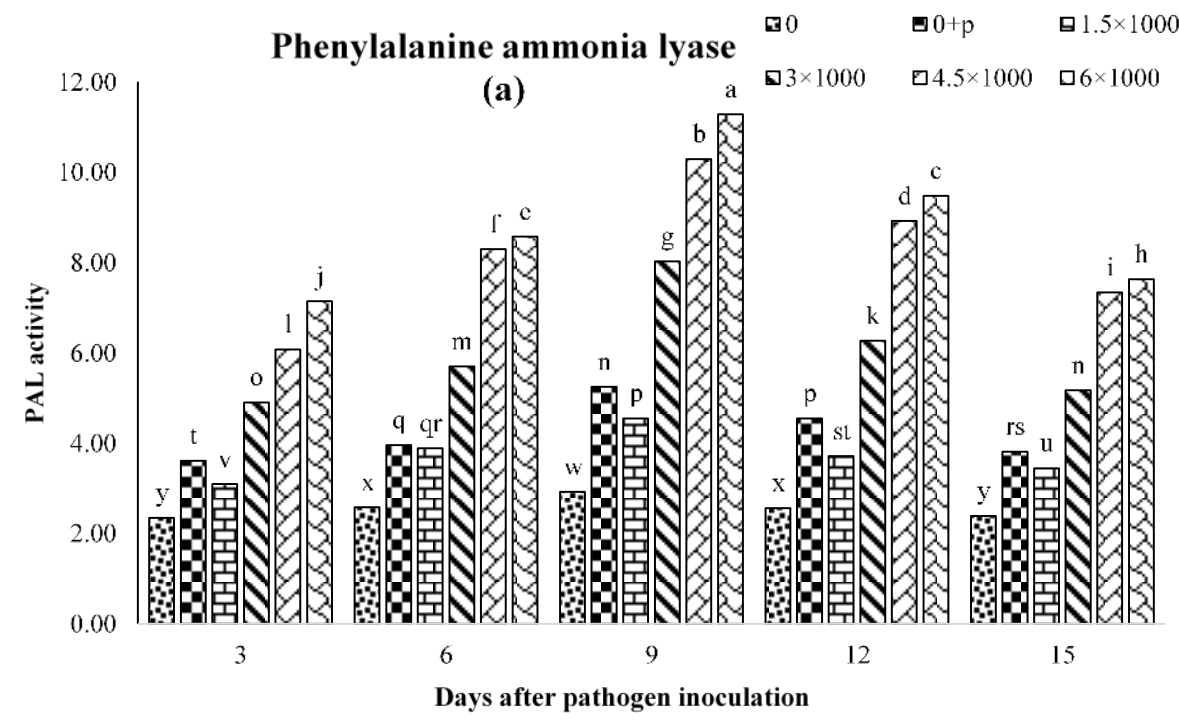

Polyphenol oxidase

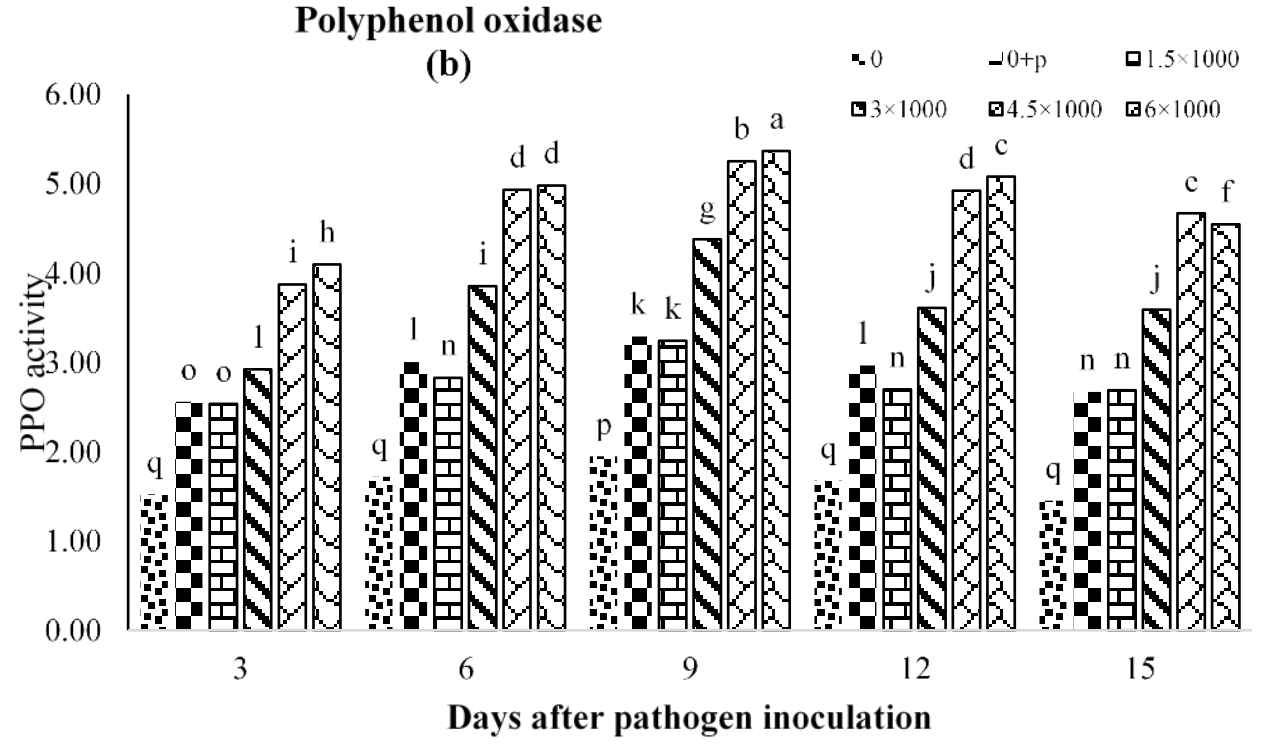

Figure 1. Effect of WGSE and $P$. expansum infection on the activity of: (a) Phenylalanine ammonia lyase (U per $\mathrm{mg}$ protein) in treated apple fruits. 

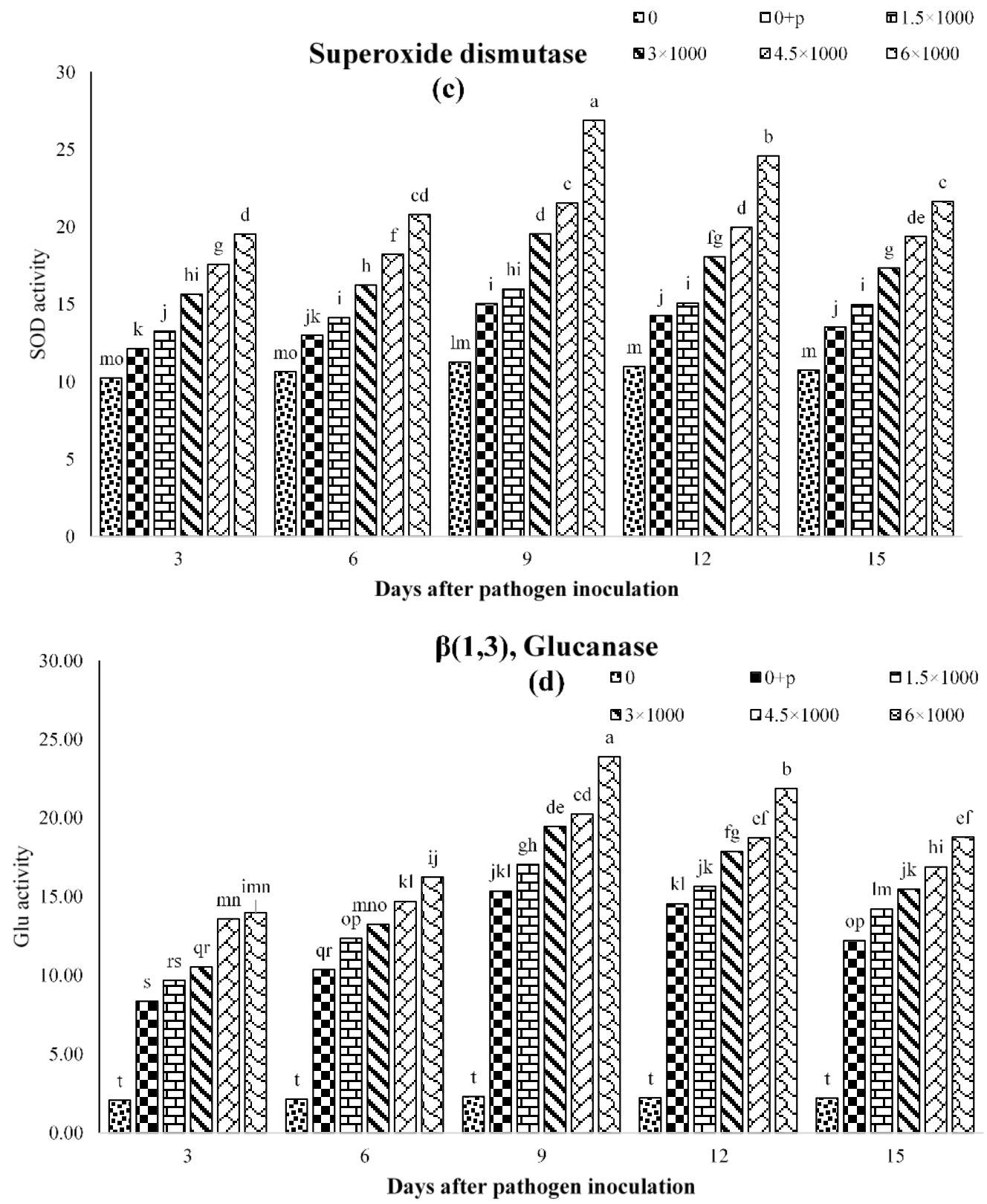

Figure 1. Effect of WGSE and $P$. expansum infection on the activity of: (c), Superoxide dismutase (U per mg mg protein) and (d) $\beta(1,3)$, Glucanase ( $\triangle \mathrm{OD}$ per min per $\mathrm{mg}$ of total protein) in treated apple fruits.

sampling times. The highest enzyme activity of PAL was observed in the apple fruits inoculated with pathogen and $6 \times 1000$ concentration at 9 days after infection with values of $4.56 \mathrm{U}$ per $\mathrm{mg}$ protein. WGSE and $P$. expansum heightened PAL activity during the entire experiment. In the absence of WGSE, the fungal infection could increase the enzyme activity, but not as effectively as WGSE. Combination of WGSE and $P$. expansum resulted in the sharp increase in PAL activity in apple fruits within 3 to 15 days and displayed a significant difference to other treatments (Figure 1a).

\section{PPO activity}

The PPO activity increased in apple fruits treated with WGSE at 3 days after pathogen infection and continued for the next 15 days after pathogen challenge. The maximum PPO activity was observed in the inoculated fruits with pathogen and $6 \times 1000$ concentration at 9 days 

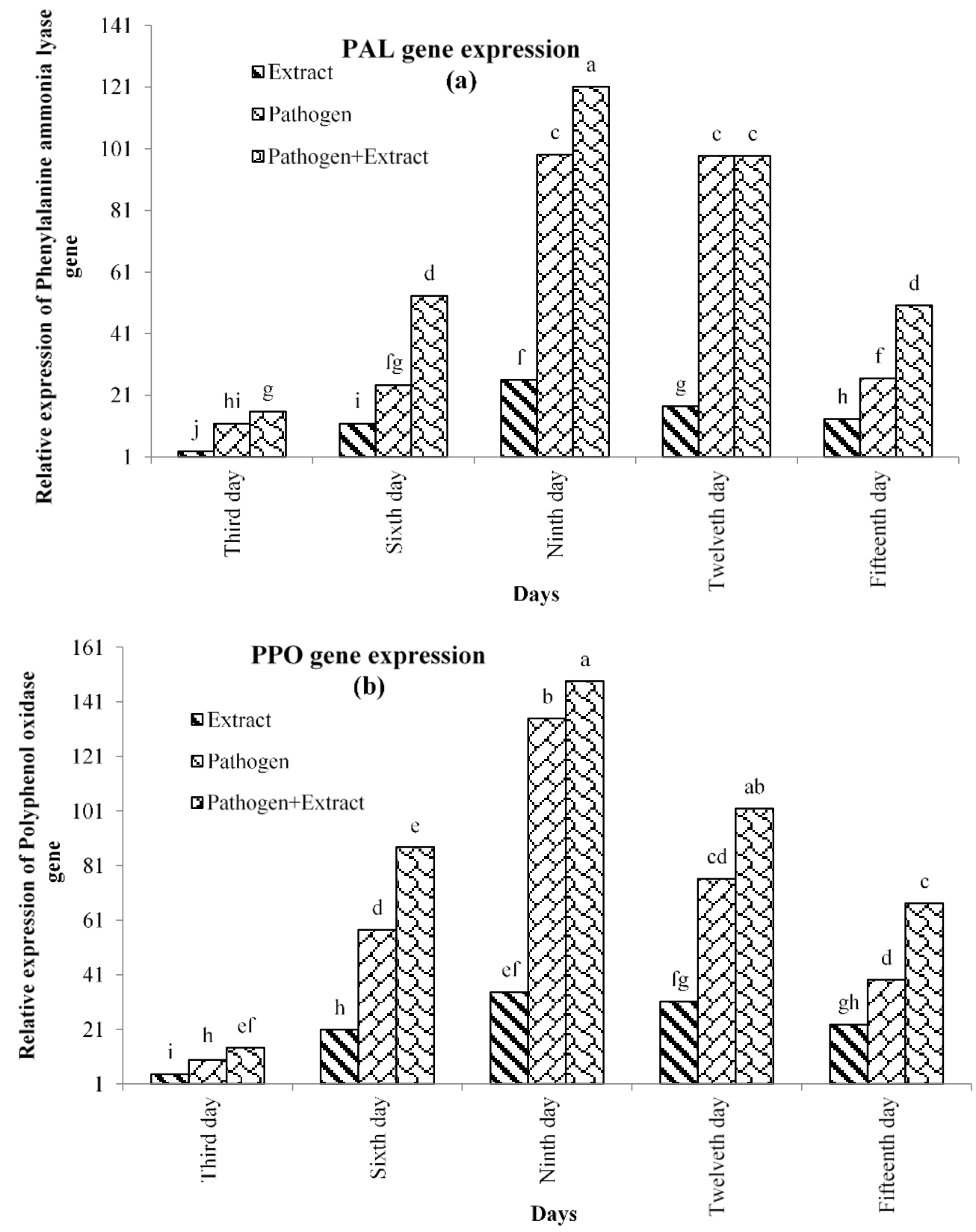

Figure 2. Effects of WGSE and pathogen on the gene expression of: (a) Phenylalanine ammonia lyase, PAL; and (b), polyphenol oxidase, PPO with real time PCR. Treatments included apple fruits treated with WGSE, pathogen and both of them. The values were significant according to Duncan's multiple range test $(p \leq 0.01)$.

after infection in the apple fruits with the value of $5.37 \Delta \mathrm{OD}$ per min per mg protein (Figure 1b).

\section{SOD activity}

The enzyme activity of SOD had the same pattern as that of PPO. SOD activity increased in the apple treated with WGSE at 3 days after pathogen infection. Activity of SOD raised significantly in both WGSE and infected plants compared to control (healthy) plants. However, in combination treatment, the SOD activity was more enhanced than in the other treatments and showed a significant difference. The activity of SOD was increased in the plant extract with $6 \times 1000$ concentration and pathogen inoculation and the peak appeared 9 days after pathogen challenge with value of $28.87 \Delta O D$ u per $\mathrm{mg}$ protein $^{-1}$ (Figure 1c). 

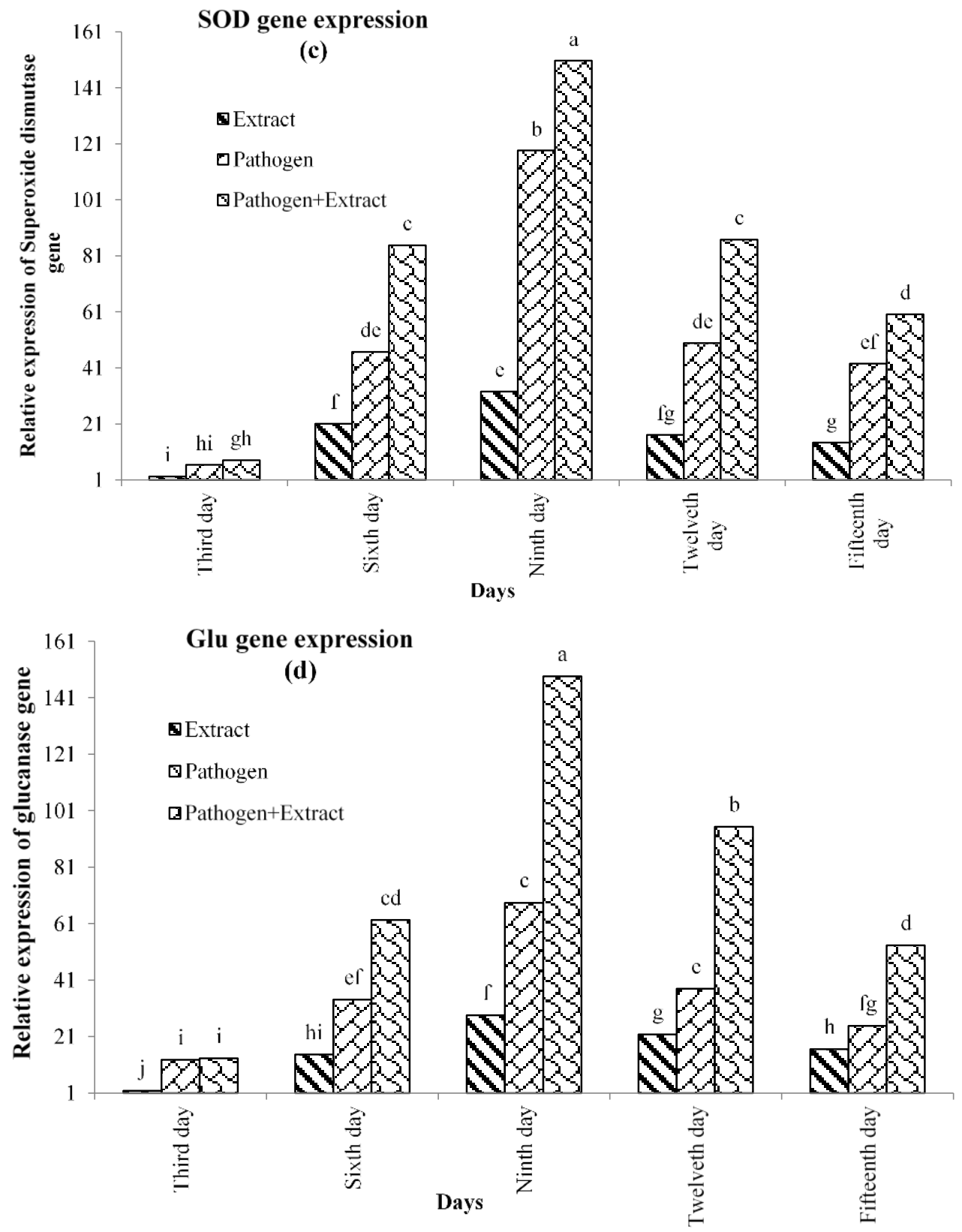

Figure 2 contd. Effects of WGSE and pathogen on the gene expression of: (c), Superoxide dismutase, SOD; and (d), $\beta(1,3), \beta(1,3)$ Glucanase, Glu with real time PCR. Treatments included apple fruits treated with WGSE, pathogen and both of them. The values were significant according to Duncan's multiple range test $(p \leq 0.01)$.

\section{Glu activity}

The Glu activity increased in the apple fruits treated with WGSE and the increase continued 9 days after pathogen inoculation in fruits and after these sampling days, it decreased. Although in pathogen inoculated plants (without WGSE), the Glu activity was increased significantly compared to control plants. The increase was lower if compared to activities of apples treated with pathogen and plant extract. The PPO activity in apples sharply increased 9 days after the plant extract treatment and this enhancement was observed in apple fruits with a significant difference with value of $23.89 \Delta \mathrm{OD}$ per min per $\mathrm{mg}$ protein.

\section{Quantitative real time PCR Analysis}

The results of quantitative expression patterns for all of genes of treated apple fruits (WGSE and pathogen) and 
different time courses are shown in Figure 2. Expression of PAL gene was gradually increased started form 3th day and reached the highest expression on the 9th day (121 times the gene expression than healthy ones). From 9th day onwards, the expression of this gene decreased, and reaching the lowest values at 15 th day.

Expression of the PPO gene increased from third day after pathogen inoculation and this trend continued until 9th day of sampling, reaching its maximum level, 148.5 times that of control. Gene expression decreased on 12th day and remained the same trend until day 15.

The expression process of SOD gene is similar to the previous two genes. The expression level of SOD gene in the third day for pathogen and plant extract treatment was 8.02 times higher than the control plant gene expression. For sixth day, the gene expression in all treatments was higher compared to the gene expression in third day. In the 12 th day, the expression level of this gene continuously decreased until 15 th day. On the 9th day, the pathogen and plant extract treatment showed the highest level of gene expression compared to the control plant.

On the ninth day of sampling, the expression of $\beta(1,3)$ Glucanase gene in the treatment and extract reached the maximum value, 148.75 times higher than in the control plant. The gene expression process increased until day 9 and then decreased. In all four genes, gene expression was always higher in pathogen than in WGSE, and when both treatments were used, the expression level was significantly increased.

\section{DISCUSSION}

The aim of this study was investigation defense strategies in apple fruits against $P$. expansum in the early time after inoculation with pathogen in the presence of WGSE as inducer. The increase in enzyme activities was reported in many plant-abiotic and plant-microorganism interactions (Chutia et al., 2012; Cass et al., 2015). It is regarded as a general defense response of the plant organism to the effect of biotic and abiotic stress (Dikilitas, 2003).

Phenylpropanoids belong to the largest group of secondary metabolites (including lignin, phytoalexins, tannins etc.) produced by plants in response to biotic and abiotic stresses (Vogt, 2010; Gholamnezhad et al., 2013). During compatible and incompatible interaction between pathogen and plants, the shikimic acid pathway is involved in plant defense due to breakdown products such as lignin, phenolics, and phytoalexins (Forell et al., 2015). PAL, SOD and PPO play important roles in biosynthesis of phenolics, phytoalexins, and lignin, the three key components responsible for disease resistance. POX decomposes indole-3-acetic acid (IAA) and has a role in the biosynthesis of lignin and defense against biotic stresses by consuming $\mathrm{H}_{2} \mathrm{O}_{2}$ in the cytosol, vacuole, and cell wall as well as in extracellular space (Gill and Tuteja, 2010). There are numerous studies that investigate the strategy of over activation of antioxidant enzymes with the ultimate aim of enhancing stress resistance in plants.

The activity of PPO and PAL enzymes was enhanced in pepper roots during interactions with Verticillium dahlia (Garmendia et al., 2006; Gholamnezhad, 2017). Koche and Choudhary (2012) showed that the activities of chitinases, 1, 3-glu-canases, and PAL were higher in tolerant cultivars of mung bean seedlings when challenged with Cercospora canescens. This induced activity of defense related enzymes was found to be associated with the tolerance status of mung bean cultivars. In the present research, PAL activity was significantly higher in all treatments of the apple fruits. PAL activity showed increasing trend from the first time (at three days after infection) to 15 days after inoculation, in apple fruits.

A direct evidence for the role of PPO in inhibiting pathogen ingress or growth comes from challenging transgenic tomato plants with enhanced or suppressed PPO levels, by the bacterial pathogen Pseudomonas syringae pv tomato. During the infection process, in PPO over-expressing plants, a reduction in bacterial growth was detected, whereas PPO anti-sense suppressed lines supported greater bacterial numbers (Thipyapong et al., 2004). The pathogen-induced PPO activity continues to be reported for a variety of plant taxa, including monocots and dicots (Deborah et al., 2001). Similarly, studies describing correlations of high PPO levels in cultivars or lines with high pathogen resistance continue to provide support for the pathogen defense role of PPO (Perez-Lopez et al., 2007). The results showed that the PPO activity of the treated apples significantly higher than that of untreated plants. PPO catalysis is the last step in the biosynthesis of lignin and other oxidative phenols. The mechanisms of PPO depend on two ways: firstly, by a direct action of PPO on the pathogen inhibition and suppression of its life cycle and secondly, induces mediated phenolic compounds which restrict the pathogen and enhance the biocontrol action (Maeda and Dudareva, 2012; Gholamnezhad, 2019).

In the present research, treatment with the WGSE enhanced the activity of all four enzymes (PAL, and PPO, SOD and Glu) during 15 days after the plants' infection with $P$. expansum. Also, pathogen treatment was more effective in increasing enzymes activity compared with the use of plant extract during 15 days after pathogen inoculation. However, treatment with plant extract combined with pathogen induced the highest activity of antioxidant enzymes. This increase reached up to twofolds of the control treatment. According to the results in this study, the WGSE increased the activity of all measured enzymes in the treated apples. The results showed that WGSE is a good inducer for enzyme activation.

WGSE was able to increase the expression of four studied genes, although the effect of the extract on gene expression was not as $P$. expansum. WGSE could increase the enzyme activity and the gene expressing 
them too. In other words, the prerequisite for increasing the activity of the enzyme is increasing its expression level. This study dramatically supports the increase in gene expression followed by increased enzyme activity (Hosseini et al., 2015). WGSE acts as an inducer.

The results of the induction of defense mechanisms involved in disease resistance of onion blight disease caused by Botrytis allii showed extract of bitter apple fruits (Citrullus colocynthis) had antagonistic effect and inhibited the mycelial growth of $B$. allii. Gas chromatography-mass spectrometry (GC-MS) analysis of bitter apple fruits showed the existence of 37 compounds and their derivatives. Greenhouse experiment approved that the extract of bitter apple fruits was the most effective in reducing disease incidence and severity, followed by $P$. chrysogenum, when they were applied 2 days preinoculation with the pathogen. A positive correlation was found between the activity of bioagents and improvement of peroxidase and phenylalanine ammonia-lyase enzymes in onion plants to resist infection with the pathogen. $P$. chrysogenum caused the highest increase in polyphenol oxidase activity in infected onion plants (Hussein et al., 2018).

The results showed that WGSE and pathogen had effect on the genes expression of $\beta(1,3)$ glucanase, but the pathogen was more effective than WGSE, and according to the glucan (enzyme substrate) in the cell walls of fungal pathogens, this enzyme was induced by pathogen. Rocket salad plant (Eruca sativa Mill.) on challenge with black spot pathogen, Alternaria brassicicola, showed that the resistant cultivar (RTM-2002) had a strong increase in a 1,3-glucanase and a chitinase compared to susceptible cultivar (T-27). Though the increase in these PR-proteins were observed in both the cultivars compared to control. The rate at which these proteins accumulated was greater in RTM-2002 than in T-27 (Gurnania et al., 2016). A. pullulans could reduce decay caused by either $B$. cinerea or $P$. expansum. In addition to controlling decay, $A$. pullulans caused a transient increase in $\beta$-1, 3-glucanase, chitinase, and peroxidase activities starting 24 hours after treatment and reaching maximum levels 48 and 96 hours after treatment. An increase in b-1,3-glucanase, chitinase, and peroxidase activity was also triggered by wounding, although, the level of increase was markedly lower than that detected in treated fruit (Ippolito et al., 2000).

The enzyme polyphenol oxidase (PPO) catalyzes the oxidation of phenolic compounds into highly reactive quinones. Polymerization of PPO-derived quinones causes the postharvest browning of cut or bruised fruit, but the native physiological functions of PPOs in undamaged, intact plant cells are not well understood. Walnut (Juglans regia) produces a rich array of phenolic compounds and possesses a single PPO enzyme, rendering it an ideal model to study PPO (Anokwuru et al., 2011). The expression of the PPO gene, like the two genes previously, was most affected by the pathogen. Although the extract also affected its expression during sampling days, the pathogen had a more significant effect on its expression. When extracts and pathogens were used simultaneously, the gene expression increased significantly, indicating that the co-administration of these two factors had a synergistic effect on gene expression.

The expression of the SOD gene, like the previouslystudied genes, was most affected by the pathogen. Although WGSE also affected its expression during sampling days, the pathogen had a more significant effect on its expression. This indicates that the pathogen can produce compounds capable of inducing the production of defense enzymes in the host. When extracts and pathogens were used simultaneously, the SOD gene expression increased significantly, indicating that the coadministration of these two factors had a synergistic effect on gene expression. Superoxide dismutase catalyzes the dismutation of superoxide anions to produce hydrogen peroxide $\left(\mathrm{H}_{2} \mathrm{O}_{2}\right)$, whereby $\mathrm{SOD}$ activity helps protect cells from damage by superoxide anion reaction products. On the other hand, the product of dismutation, $\mathrm{H}_{2} \mathrm{O}_{2}$, is also a potentially hazardous compound and can be metabolized to $\mathrm{H}_{2} \mathrm{O}_{2}$ by a wide array of antioxidant enzymes such as catalase and peroxidase. However, when POD metabolizes $\mathrm{H}_{2} \mathrm{O}_{2}$, it oxidizes hydrogen donors at the same time. A wide range of hydrogen donors, including polyphenols, can be oxidized by POD, and involvement of $P O D$ in enzymatic browning has been reported (Lee et al., 2012). A lower CAT level in apples was reported to be related to superficial scald development (Rao et al., 1998).

The surprising result of this study was the excellent coordination between the activity of the enzyme and the expression level of the genes associated with each enzyme. As the amount of enzyme activity increases, the expression level of the related gene first increases and then this increase in expression of the corresponding enzyme increases.

Pepper ascorbate peroxidase-like (CAPOA1), thioredoxin peroxidase-like (CAPOT1), and peroxidaselike (CAPO1) clones were isolated from pepper leaves inoculated with avirulent strain Bv5-4a of Xanthomonas campestris pv. vesicatoria. CAPOA1, CAPOT1, and CAPO1 mRNA disappeared 18 to 30 hours after the bacterial infection when the hypersensitive response (HR) was visible. In contrast, peroxidase activity reached a peak at $18 \mathrm{~h}$ after infection and then declined at 24 and $30 \mathrm{~h}$ when $\mathrm{H}_{2} \mathrm{O}_{2}$ accumulation level was maximal. These results suggest that the striking accumulation of $\mathrm{H}_{2} \mathrm{O}_{2}$ and strong decrease in peroxidase activity during the programmed cell death may be due to the strong suppression of CAPOA1, CAPOT1, and CAPO1 gene expression (Do et al., 2002). These results confirm the results in this study when the enzyme gene expression increase, the enzyme activity increase too.

A research carried out on the influence of drought stress during the flowering stage of 2 canola cultivars on some physiological characteristics, antioxidant activities, and gene expression of antioxidant enzymes show that a 
significant positive correlation was indicated between shoot dry materials with relative water content percentage, catalase activity, ascorbate peroxidase activity, and cytosolic ascorbate peroxidase relative gene expression ratio. Antioxidant enzymatic activity and the association between gene transcript levels and activity seem to play roles in protecting plants from oxidative damage in drought stress (Hosseini el al., 2015). Their results confirmed the findings in this study that as gene expression increases, the activity of the related enzyme also increases.

\section{CONFLICT OF INTEREST}

The authors declare that they have no conflict of interest.

\section{REFERENCES}

Anokwuru, C. P., Anyasor, G. N., Ajibaye, O., Fakoya, O., \& Okebugwu, P. (2011). Effect of extraction solvents on phenolic, flavonoid and antioxidant activities of three Nigerian medicinal plants. Nature and Science, 9(7), 53-61.

Araji, S., Grammer, T. A., Gertzen, R., Anderson, S. D., MikulicPetkovsek, M., Veberic, R., Phu, M. L., Solar, A., Leslie, C. A., Dandekar, A. M., \& Escobar, M. A. (2014). Novel roles for the polyphenol oxidase enzyme in secondary metabolism and the regulation of cell death in walnut. Plant Physiology, 164(3), 1191-1203.

Blanco, F., Salinas, P., Cecchini, N. M., Jordana, X., Van Hummelen, P., Alvarez, M. E., \& Holuigue, L. (2009). Early genomic responses to salicylic acid in Arabidopsis. Plant Molecular Biology, 70(1-2), 79-102.

Cosentino, S. C. I. G., Tuberoso, C. I. G., Pisano, B., Satta, M. L., Mascia, V., Arzedi, E., \& Palmas, F. (1999). In-vitro antimicrobial activity and chemical composition of Sardinian thymus essential oils. Letters in applied microbiology, 29(2), 130-135.

Deborah, S. D., Palaniswami, A., Vidhyasekaran, P., \& Velazhahan, R. (2001). Time-course study of the induction of defense enzymes, phenolics and lignin in rice in response to infection by pathogen and non-pathogen. Journal of Plant Diseases and Protection, 108(2), 204-216.

Errampalli, D. (2004). Effect of fludioxonil on germination and growth of Penicillium expansum and decay in apple cvs. Empire and Gala. Crop Protection, 23(9), 811-817.

Feldberg, R. S., Chang, S. C., Kotik, A. N., Nadler, M., Neuwirth, Z., Sundstrom, D. C., \& Thompson, N. H. (1988). In vitro mechanism of inhibition of bacterial cell growth by allicin. Antimicrobial Agents and Chemotherapy, 32(12), 17631768.

Forell, G. V., Robertson, D., Lee, S. Y., \& Cook, D. D. (2015). Preventing lodging in bioenergy crops: a biomechanical analysis of maize stalks suggests a new approach. Journal of Experimental Botany, 66(14), 4367-4371.

Garmendia, I., Aguirreolea, J., \& Goicoechea, N. (2006). Defence-related enzymes in pepper roots during interactions with arbuscular mycorrhizal fungi and/or Verticillium dahliae. BioControl, 51, Article number 293.

Gholamnejad, J. (2009). Studies on biological control of blue mold in apple by some yeast isolates and their mechanisms of antagonism (Doctoral dissertation, M. Sc. dissertation, University of Tehran. P. 152(In Farsi).
Gholamnejad, J., Etebarian, H. R., Roustaee, A., \& Sahebani, N. A. (2009). Biological control of apples blue mold by isolates of Saccharomyces cerevisiae. Journal of Plant Protection Research, 49(3), 270-275.

Gholamnezhad J (2017) Effect of plant extracts against apple gray mold caused by Botrytis cinerea. Applied Microbiology in Food Industries, 3(1), 53-66

Gholamnezhad, J. (2019). Effect of plant extracts on activity of some defense enzymes of apple fruit in interaction with Botrytis cinerea. Journal of Integrative Agriculture, 18(1), 115-123.

Gholamnezhad, J., Sanjarian, F., Mohammadi goltapeh, E., Safaei, N., \& Razavi, K. H. (2013). The evaluation of salicylic acid effect on septorios disease by Mycospharella graminicola, Research in Plant Pathology, 2(2):35-46

Gill, S. S., \& Tuteja, N. (2010). Reactive oxygen species and antioxidant machinery in abiotic stress tolerance in crop plants. Plant Physiology and Biochemistry, 48(12), 909-930.

Gurnani, N., Gupta, M., Mehta, D., \& Mehta, B. K. (2016). Chemical composition, total phenolic and flavonoid contents, and in vitro antimicrobial and antioxidant activities of crude extracts from red chilli seeds (Capsicum frutescens L.). Journal of Taibah University for Science, 10(4), 462-470.

Hosseini, S. M., Hasanloo, T., \& Mohammadi, S. (2015). Physiological characteristics, antioxidant enzyme activities, and gene expression in 2 spring canola (Brassica napus L.) cultivars under drought stress conditions. Turkish Journal of Agriculture and Forestry, 39(3), 413-420.

Hussein, M. M., Abo-Elyousr, K. A., Hassan, M. A., Hashem, M., Hassan, E. A., \& Alamri, S. A. (2018). Induction of defense mechanisms involved in disease resistance of onion blight disease caused by Botrytis allii. Egyptian Journal of Biological Pest Control, 28, Article number 80.

Ippolito, A., El Ghaouth, A., Wilson, C. L., \& Wisniewski, M. (2000). Control of postharvest decay of apple fruit by Aureobasidium pullulans and induction of defense responses. Postharvest Biology and Technology, 19(3), 265272.

Koche, D., \& Choudhary, A. (2012). Induction of hydrolases and phenylalanine ammonia-lyase by pathogen derived elicitors in mungbean (Vigna radiata L.). Electronic Journal of Biology, 8(1), 11-14.

Lee, M. R. F., Tweed, J. K. S., \& Sullivan, M. L. (2013). Oxidation of ortho-diphenols in red clover with and without polyphenol oxidase (PPO) activity and their role in PPO activation and inactivation. Grass and Forage Science, 68(1), 83-92.

Maeda, H., \& Dudareva, N. (2012). The shikimate pathway and aromatic amino acid biosynthesis in plants. Annual Review of Plant Biology, 63, 73-105.

Maoz, M., \& Neeman, I. (1998). Antimicrobial effects of aqueous plant extracts on the fungi Microsporum canis and Trichophyton rubrum and on three bacterial species. Letters in Applied Microbiology, 26, 61-63.

Mari, M., Guidarelli, M., Martini, C., \& Spadoni, A. (2012). First report of Colletotrichum acutatum causing bitter rot on apple in Italy. Plant Disease, 96(1), 144-144.

Morales, H., Marín, S., Ramos, A. J., \& Sanchis, V. (2010). Influence of post-harvest technologies applied during cold storage of apples in Penicillium expansum growth and patulin accumulation: A review. Food Control, 21(7), 953-962.

Niem, J., Miyara, I., Ettedgui, Y., Reuveni, M., Flaishman, M., \& Prusky, D. (2007). Core rot development in red delicious apples is affected by susceptibility of the seed locule to Alternaria alternata colonization. Phytopathology, 97(11), 1415-1421. 
Perez-Lopez, A. J., del Amor, F. M., Serrano-Martínez, A., Fortea, M. I., \& Núñez-Delicado, E. (2007). Influence of agricultural practices on the quality of sweet pepper fruits as affected by the maturity stage. Journal of the Science of Food and Agriculture, 87(11), 2075-2080.

Sever, Z., Ivić, D., Kos, T., \& Miličević, T. (2012). Identification of Fusarium species isolated from stored apple fruit in Croatia. Archives of Industrial Hygiene and Toxicology, 63(4), 463-470.

Shi, C., Dai, Y., Xia, B., Xu, X., Xie, Y., \& Liu, Q. (2001). The purification and spectral properties of polyphenol oxidase I fromNicotiana tabacum. Plant Molecular Biology Reporter, 19(4), 381-382.

Sutton, T. B., Aldwinckle, H. S., Agnello, A. M., \& Walgenbach, J. F. (Eds.). (2014). Compendium of apple and pear diseases and pests. St. Paul, MN: American Phytopathological Society.

Thipyapong, P., Hunt, M. D., \& Steffens, J. C. (2004). Antisense downregulation of polyphenol oxidase results in enhanced disease susceptibility. Planta, 220, 105-117.

Vero, S., Mondino, P., Burgaeno, J., Soubes, M., \& Wisniewski, M. (2002) Chracterizatioin of biological activity of two yeast strains from Uruguay against blue mold of apple. Postharvest Biology and Technology, 26, 91-98.

Vogt, T. (2010). Phenylpropanoid biosynthesis. Molecular Plant, 3(1), 2-20.
Wang, J. W., Zheng, L. P., Wu, J. Y., \& Tan, R. X. (2006). Involvement of nitric oxide in oxidative burst, phenylalanine ammonia-lyase activation and Taxol production induced by low-energy ultrasound in Taxus yunnanensis cell suspension cultures. Nitric Oxide, 15(4), 351-358.

Weber, R. W. (2011). Phacidiopycnis washingtonensis, cause of a new storage rot of apples in Northern Europe. Journal of Phytopathology, 159(10), 682-686.

Winterbourn, C. C., Hawkins, R. E., Brian, M., \& Carrell, R. W. (1975). The estimation of red cell superoxide dismutase activity. The Journal of Laboratory and Clinical Medicine, 85(2), 337-341.

Xiao, C. L., \& Boal, R. J. (2009). Preharvest application of a boscalid and pyraclostrobin mixture to control postharvest gray mold and blue mold in apples. Plant Disease, 93(2), 185-189.

Yuliani, S., \& Rusli, S. (2003). Extraction of botanical pesticides. Indonesian Spice and Medicinal Crops Research Institute. Bogor. p. 17. 